\title{
Mineralogy and Geochemistry of Sediments from Lake Tuz
}

Mehmet Yavuz Huseyinca (D) Suayip Kupeli (D)

Konya Technical University, Department of Geological Engineering, Konya, Turkey

A B S T R AC T
ake Tuz is a closed basin in the center of Anatolia (Turkey) with shallow hypersaline wa-
ter. In this study, mineralogical and geochemical features of the lake sediments sampled
by core drillings were investigated. Halite, polyhalite, calcite, magnesite, dolomite, huntite,
quartz, and albite minerals were found in bulk sample and montmorillonite and vermiculite
minerals were determined in the clay fraction XRD analyses. In geostatistical evaluations,
elements are grouped into four clusters which are named Clastic, Hydrothermal, Evaporite-
carbonate and Evaporite-sulfate. Trace elements included in the clastic cluster were used to
constrain provenance and tectonic setting. The Light Rare Earth Element (LREE)-enriched
REE pattern suggests a cratonic provenance for the lake sediments, except for the low nega-
tive Eu anomaly. Trace element ratios of La/Sc, La/Co, Th/Sc, Th/Co, Zr/Sc, Zr/Co, Ba/
Sc, and Ba/Co, which are critical for provenance, show a provenance of "felsic-intermediate
magmatic" composition. According to the La-Th-Sc diagram, the tectonic setting of the
source area was found as "Continental Island Arc".

Article History:

Received: 2021/11/11

Accepted: $2021 / 11 / 30$

Online: $2021 / 12 / 31$

Correspondence to: Mehmet Yavuz HÜSEYINCA,

E-mail:myhuseyinca@ktun.edu.tr; Phone: +90 3322051839 ;

Fax: +90 2052410635

\section{Keywords:}

Central Anatolia; Lake Tuz; Provenance; Sediment geochemistry; Tectonic setting

\section{INTRODUCTION}

L ake Tuz is located in the center of Anatolia (Fig. 1 ), and is the second largest lake of Turkey with a surface area of $1665 \mathrm{~km}^{2}$. The lake includes hypersaline water, is fed by groundwater and rainwater in the autumn-winter season and without outflow [1]. The most important streams reaching the lake are Uluirmak, İnsuyu and Peçeneközü. The lake consists of two different parts; a shallow (main lake, hereafter Lake Tuz) with a large area and a deep one with a smaller area [2]. The depth of the lake water does not exceed one meter. Towards the end of the summer, approximately half of the lake floor is exposed following the evaporation of the saline water [3-6]. Also, both table salt and industrial salt are produced in the salt pans, which are separated from the lake with barriers [7].

According to Irion and Müller [8], playa sediments are largely composed of mud (silty clay) varying in colour from white through grey to black, and contains huntite, dolomite, magnesite, polyhalite, and gypsum. Uygun and Şen [9] showed that the geochemistry of the water does not show a standard composition due to the large seasonal variations. Çamur and Mutlu [10] stated that the sediments are mainly composed of gypsum, do- lomite, huntite, magnesite, and polyhalite minerals. K1lıç and Kılıç [11] reported that the lake water is of $\mathrm{Na}-\mathrm{K}$ $\mathrm{Mg}-\mathrm{Cl}-\mathrm{SO}_{4}$ type and the muddy sediments up to $20 \mathrm{~cm}$ deep under the salt crust contain gypsum, magnesite, thenardite, polyhalite, aragonite, and montmorillonite.

In this study, the mineralogy and geochemistry of the lake sediments, which are sampled by core drillings not exceeding one meter in depth, were investigated. It is aimed to evaluate the sediment composition by geostatistical analyses, and to infer their provenance and tectonic settings by geochemical data.

\section{Geological Background}

The current (Holocene) Lake Tuz [13] is located within the Tuzgölü basin [14-19]. The east-northeast of the lake is bordered by the Tuzgölü Fault Zone (TFZ) [20-22]. To the east of this fault zone is the Kırşehir Massif [23-30]. It is stated that the detrital material supply to the lake is mostly originates from Kırşehir Massif due to the difference in elevation [18]. The south and west of the lake are surrounded by plains, where the Quaternary aged old lake terraces take place [31]. 


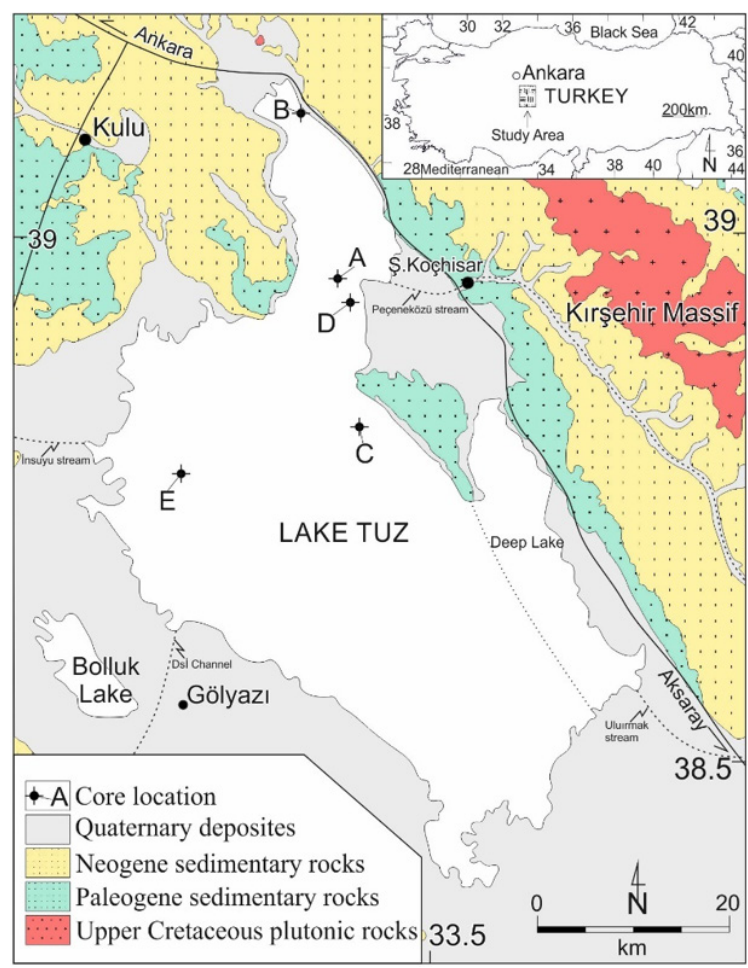

Figure 1. The geological map of the close vicinity of the Lake Tuz (modified from [12]) and the drilling locations (A-E).

\section{MATERIAL AND METHODS}

Five cores with depths varying between 48 and $78 \mathrm{~cm}$ were taken from the lake floor with a hand-held drilling

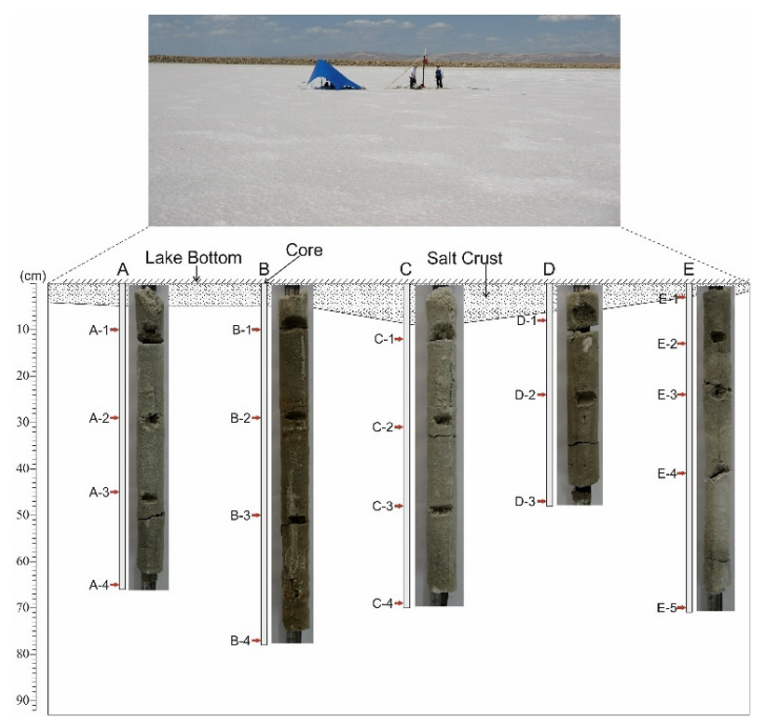

Figure 2. Sediment cores and depth of samples.

machine (Fig. 2). Samples were arranged from different depths of these cores. XRD analyses of the bulk samples were performed in MTA (Turkey) laboratories. Powdered samples were analysed with Bruker D-8 Advance brand machine that have a $2.2 \mathrm{~kW}$ cupper X-Ray anode. XRD analyses of the clay fraction were made by standard, ethylene glycol, $300{ }^{\circ} \mathrm{C}$ heat-treated and $550{ }^{\circ} \mathrm{C}$ heat-treated samples. SEM-EDX analyses were performed in SelçukİLTEK (Turkey) laboratories using the ZEISS EVO-LS10 brand SEM device with EDX addition and using $\mathrm{LaB}_{6}$ fi-
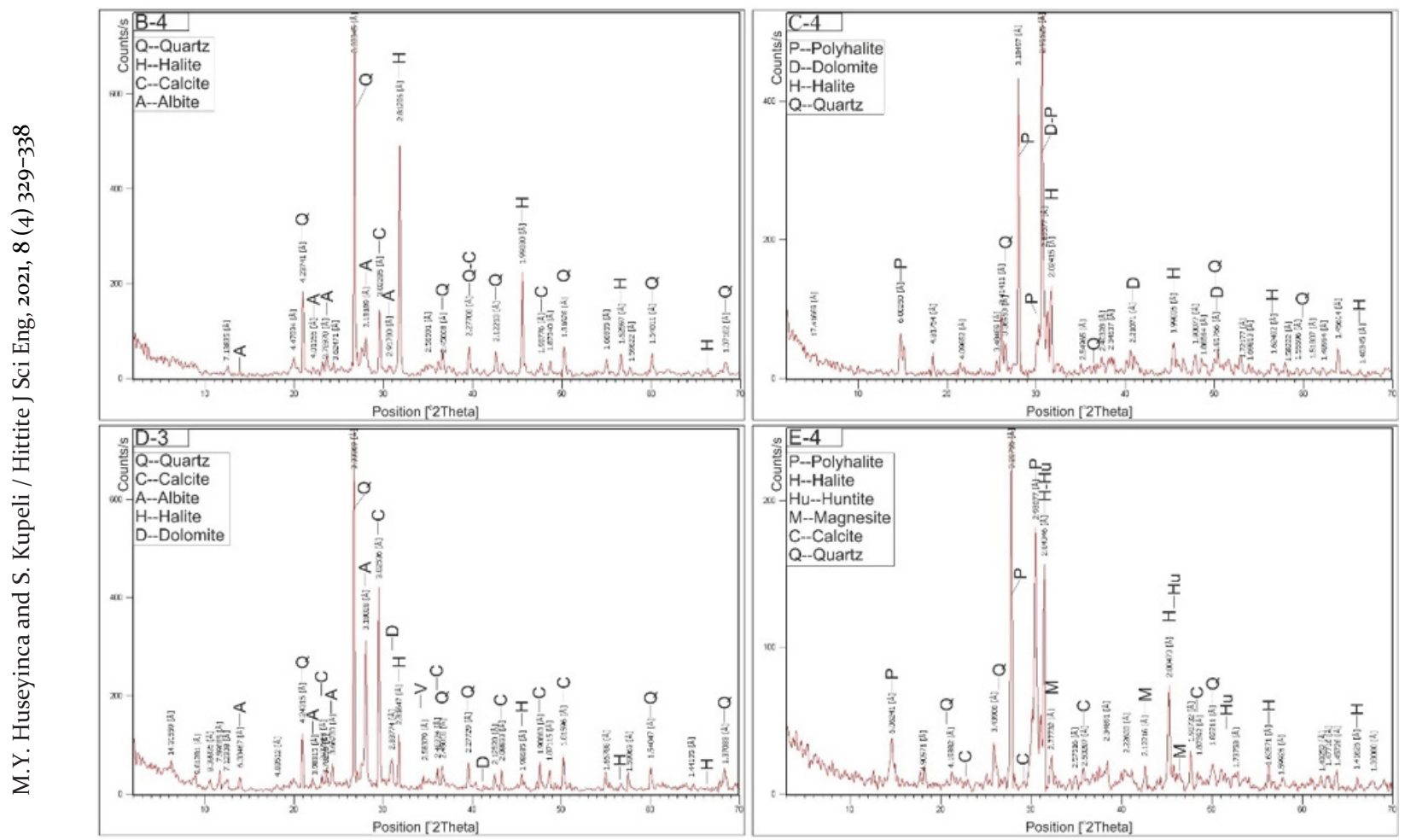

Figure 3. XRD analyses of the bulk samples from depths B-4, C-4, D-3 and E-4. 
lament as an electron source. Geochemical analyses were carried out in ACME (Canada) laboratories by Lithium Borate Fusion method. A 0.2 g weighed powder sample was poured into a graphite crucible and mixed with 1.5 $\mathrm{g}$ of $\mathrm{LiBO}_{2} / \mathrm{Li}_{2} \mathrm{~B}_{4} \mathrm{O}_{7}$ flux. The mixture was melted and then dissolved in $100 \mathrm{ml}$ of $5 \% \mathrm{HNO}_{3}$. Solution samples were analysed by ICP-ES and ICP-MS. The LOI (Loss on Ignition) was calculated by the weight difference for a 1 g. sample after ignition at $950{ }^{\circ} \mathrm{C}$ for 90 minutes. Total carbon (TOT/C) and total sulfur (TOT/S) contents were measured by Leco. Chondrite [32] and Post Archean Australian Shale (PAAS) contents [33] were used for normalization. Chondrite normalized $\mathrm{Ce}$ and $\mathrm{Eu}$ anomalies were calculated by $\left.\left(\mathrm{Ce} / \mathrm{Ce}^{*}\right)_{\mathrm{cn}}=\left[\mathrm{Ce}_{\mathrm{cn}} /\left[\left(\mathrm{La}_{\mathrm{cn}}\right) \cdot\left(\mathrm{Pr}_{\mathrm{cn}}\right)\right]^{0.5}\right]\right)$ and $\left(\mathrm{Eu} / \mathrm{Eu}^{*}\right)_{\mathrm{cn}}=\left[\mathrm{Eu}_{\mathrm{cn}} /\left[\left(\mathrm{Sm}_{\mathrm{cn}}\right) \cdot\left(\mathrm{Gd}_{\mathrm{cn}}\right)\right]^{0.5}\right]$ formulas, respectively (cn: chondrite normalized).

\section{RESULTS AND DISCUSSION}

\section{Mineralogy}

The lake sediments sampled with cores are white-greybrown in colour. In XRD analyses of samples representing different depths, mineral compositions consisting of halite, polyhalite, calcite, magnesite, dolomite, huntite, quartz, and albite were detected (Fig. 3). In the clay fraction XRD analyses montmorillonite and vermiculite minerals were detected (Fig. 4). The presence of quartz and polyhalite crystals were observed in SEM-EDX analyses (Fig. 5).

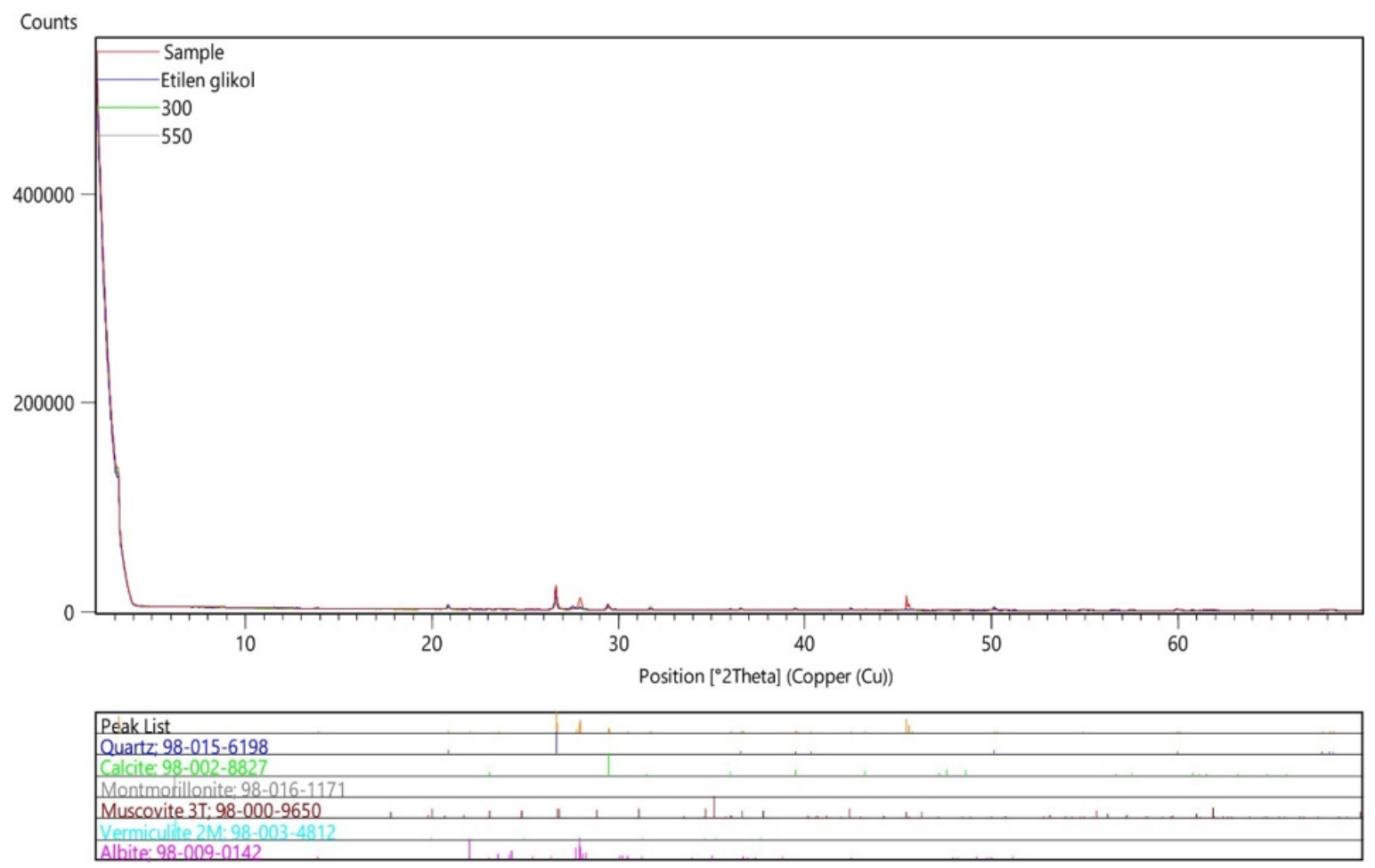

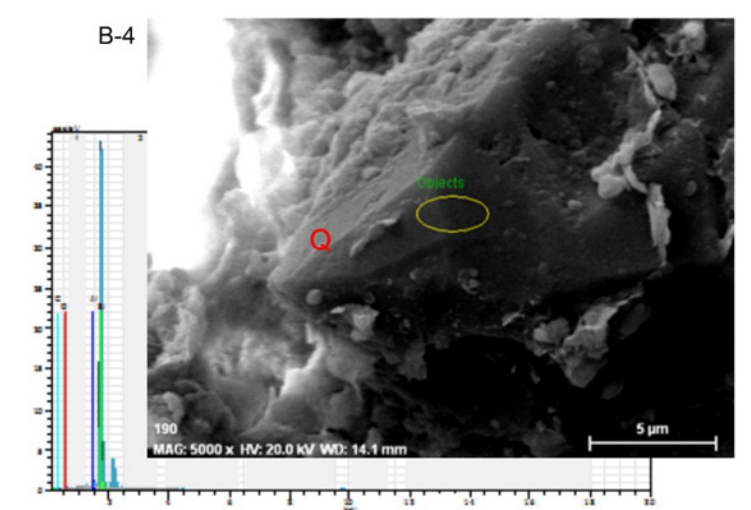

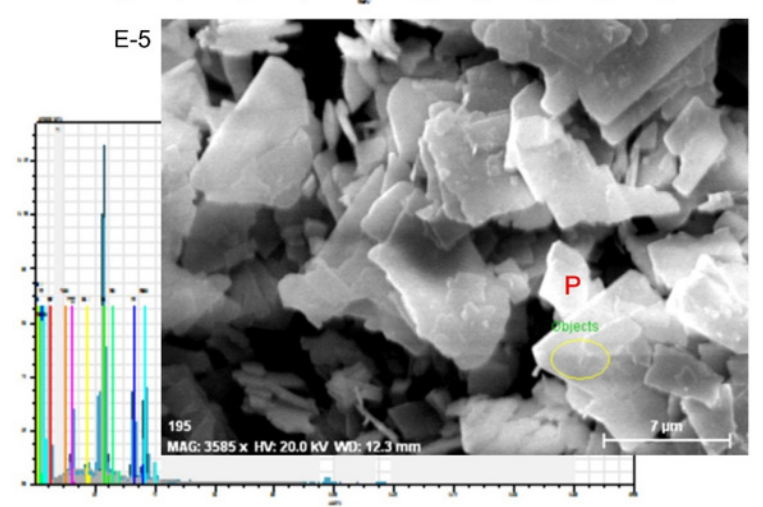

Figure 5. SEM images and EDX analyses (yellow circle) of euhedral quartz (Q) in sample B-4 and euhedral polyhalite (P) crystals in sample E-5.

Figure 4. XRD analyses of the clay fraction. 


\section{Whole-rock Geochemistry}

The major and trace element concentrations of 20 samples taken from different depths of five cores are shown in Table 1.

Major oxide concentrations were highly variable in samples (Table 1). Mineralogical compositions suggest that this variability is due to the mixture of evaporites and clastics at different ratios. In Fig. 6, the major oxides were divided by their $\mathrm{Al}_{2} \mathrm{O}_{3}$ concentrations, and compared with PAAS [34]. Such normalization may reveal major oxide enrichments originating from the evaporitic phase. Considering the sample average in the graph, $\mathrm{Fe}_{2} \mathrm{O}_{3} / \mathrm{Al}_{2} \mathrm{O}_{3}, \mathrm{TiO}_{2} /$ $\mathrm{Al}_{2} \mathrm{O}_{3}, \mathrm{P}_{2} \mathrm{O}_{5} / \mathrm{Al}_{2} \mathrm{O}_{3}$, and $\mathrm{MnO} / \mathrm{Al}_{2} \mathrm{O}_{3}$ overlapped with that of PAAS. However, there is a significant enrichment in $\mathrm{MgO} /$ $\mathrm{Al}_{2} \mathrm{O}_{3}, \mathrm{CaO} / \mathrm{Al}_{2} \mathrm{O}_{3}, \mathrm{Na}_{2} \mathrm{O} / \mathrm{Al}_{2} \mathrm{O}_{3}$, and $\mathrm{K}_{2} \mathrm{O} / \mathrm{Al}_{2} \mathrm{O}_{3}$ ratios of the samples, probably due to the evaporite minerals, as determined in XRD analyses. The slight enrichment in $\mathrm{SiO}_{2} / \mathrm{Al}_{2} \mathrm{O}_{3}$ ratio is due to the abundance of quartz. In addition, the enrichment of $\mathrm{Cr}_{2} \mathrm{O}_{3} / \mathrm{Al}_{2} \mathrm{O}_{3}$ may indicate a contribution from an ophiolitic source [35].

The PAAS normalized plot of trace element concentrations divided by $\mathrm{Al}_{2} \mathrm{O}_{3}$ is shown in Fig. 7. In the graph, $\mathrm{Sc} /$ $\mathrm{Al}_{2} \mathrm{O}_{3}, \mathrm{Ba} / \mathrm{Al}_{2} \mathrm{O}_{3}, \mathrm{Co} / \mathrm{Al}_{2} \mathrm{O}_{3}, \mathrm{Cs} / \mathrm{Al}_{2} \mathrm{O}_{3}, \mathrm{Ga} / \mathrm{Al}_{2} \mathrm{O}_{3}, \mathrm{Hf} / \mathrm{Al}_{2} \mathrm{O}_{3}$, $\mathrm{Nb} / \mathrm{Al}_{2} \mathrm{O}_{3}, \mathrm{Rb} / \mathrm{Al}_{2} \mathrm{O}_{3}, \mathrm{Th} / \mathrm{Al}_{2} \mathrm{O}_{3}, \mathrm{~V} / \mathrm{Al}_{2} \mathrm{O}_{3}, \mathrm{Zr} / \mathrm{Al}_{2} \mathrm{O}_{3}, \mathrm{Cu} / \mathrm{Al}_{2} \mathrm{O}_{3}$, and $\mathrm{Y} / \mathrm{Al}_{2} \mathrm{O}_{3}$ overlapped with PAAS. However, $\mathrm{Sr} / \mathrm{Al}_{2} \mathrm{O}_{3}, \mathrm{U} /$ $\mathrm{Al}_{2} \mathrm{O}_{3}, \mathrm{Mo} / \mathrm{Al}_{2} \mathrm{O}_{3}, \mathrm{~Pb} / \mathrm{Al}_{2} \mathrm{O}_{3}$, and $\mathrm{Ni} / \mathrm{Al}_{2} \mathrm{O}_{3}$ were enriched. $\mathrm{Sr}$ enrichment may have occurred due to the evaporitic phase. The enrichment of $\mathrm{Pb}$ and $\mathrm{Zn}$ may be due to hydrothermal solutions or $\mathrm{Pb}-\mathrm{Zn}$ mineralizations at the source. $\mathrm{U}$ and $\mathrm{Mo}$ may be enriched due to the redox conditions [36]. Ni may be enriched due to the ophiolitic source.

In the similarity dendrogram prepared according to the Pearson Correlation Coefficients, the variables showing strong similarity with each other form 4 clusters (Fig. 8). The first cluster consists of $\mathrm{SiO}_{2}, \mathrm{Al}_{2} \mathrm{O}_{3}, \mathrm{Fe}_{2} \mathrm{O}_{3}, \mathrm{TiO}_{2}, \mathrm{P}_{2} \mathrm{O}_{5}$, $\mathrm{MnO}, \mathrm{Cr}_{2} \mathrm{O}_{3}, \mathrm{Sc}, \mathrm{Ba}, \mathrm{Co}, \mathrm{Ga}, \mathrm{Hf}, \mathrm{Nb}, \mathrm{Rb}, \mathrm{Th}, \mathrm{V}, \mathrm{Zr}, \mathrm{Cu}, \mathrm{Ni}$, and $\Sigma$ REE variables; the second cluster $\mathrm{Cs}, \mathrm{Pb}, \mathrm{Zn}$, and $\mathrm{As}$ variables; the third cluster consists of $\mathrm{MgO}, \mathrm{Na}_{2} \mathrm{O}$, TOT/C, $\mathrm{U}, \mathrm{Mo}$, and $\mathrm{Ce} / \mathrm{Ce}^{*}$ variables; and the fourth cluster consists of $\mathrm{CaO}, \mathrm{K}_{2} \mathrm{O}$, $\mathrm{LOI}, \mathrm{TOT} / \mathrm{S}$, and $\mathrm{Sr}$ variables. The first cluster is named "Clastic" because of the associations with $\mathrm{SiO}_{2}$, $\mathrm{Al}_{2} \mathrm{O}_{3}, \mathrm{TiO}_{2}$, and $\Sigma \mathrm{REE}$. The second cluster originates from possible $\mathrm{Pb}-\mathrm{Zn}$ mineralization or hydrothermal solutions in the source area and was named "Hydrothermal". The third cluster was named "Evaporite-carbonate" because of its association with TOT/C. It is known that $\mathrm{U}$ and $\mathrm{Mo}$ in this cluster are enriched under reducing conditions. The $\mathrm{Ce}$ anomaly association shows that the elements in this group are affected from redox conditions. Finally, the fourth clus-

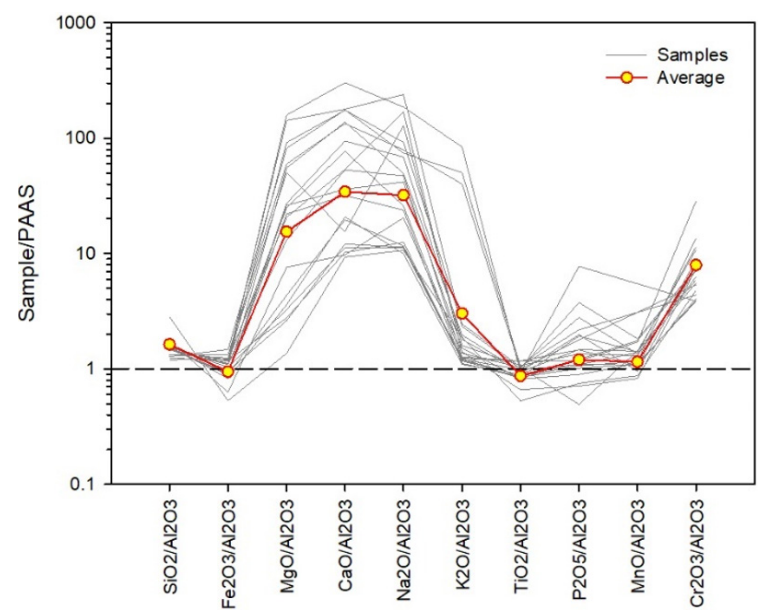

Figure 6. Element $/ \mathrm{Al}_{2} \mathrm{O}_{3}$ comparison of major oxides with PAAS [34].

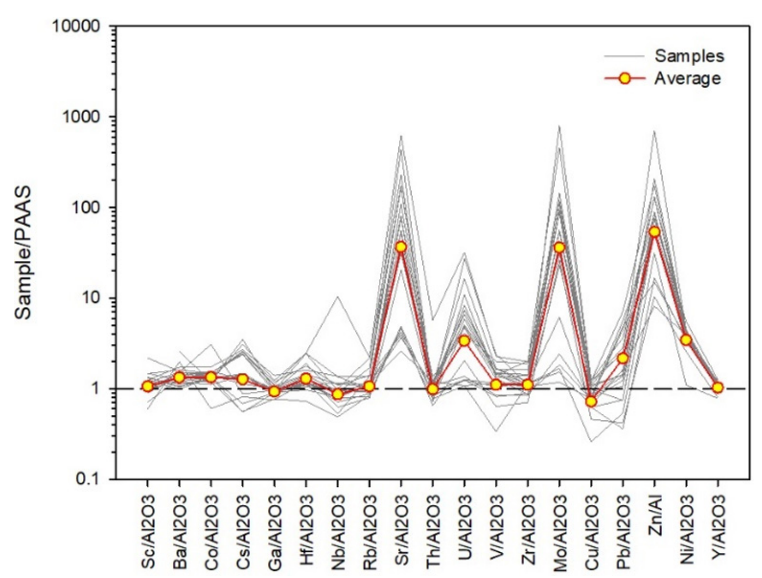

Figure 7. Element/ $\mathrm{Al}_{2} \mathrm{O}_{3}$ comparison of trace elements with PAAS [34].

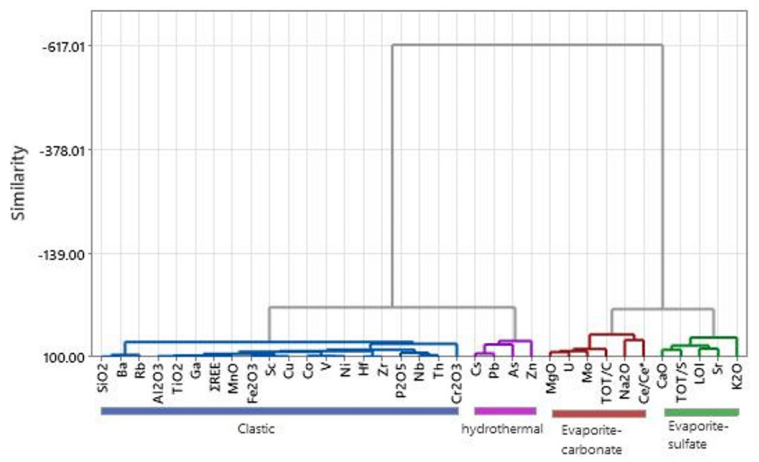

Figure 8. Dendrogram of variables

ter represents sulfates due to their association with TOT/S and was named "Evaporite-sulfate". It is understood that the LOI in this group is of gypsum origin and secondary carbonate origin due to the connection of the fourth cluster with the third cluster.

\section{Provenance}

There is a significant enrichment in the concentrations of $\mathrm{MgO}, \mathrm{CaO}, \mathrm{Na}_{2} \mathrm{O}$ and $\mathrm{K}_{2} \mathrm{O}$ which are associated with evaporites (Fig. 6). Also, they are not associated with clas- 
Table 1a.Major (\%) and trace element (ppm) concentrations.

\begin{tabular}{|c|c|c|c|c|c|c|c|c|c|c|c|}
\hline & $A_{1}$ & $A_{2}$ & $A_{3}$ & $A_{4}$ & $B_{1}$ & $B 2$ & $B_{3}$ & $B_{4}$ & $C_{1}$ & $\mathrm{C}_{2}$ & $c_{3}$ \\
\hline $\mathrm{SiO}_{2}$ & 24.03 & 12.09 & 19.71 & 48.63 & 73.98 & 50.31 & 48.06 & 46.26 & 4.54 & 6.31 & 9.13 \\
\hline $\mathrm{Al}_{2} \mathrm{O}_{3}$ & 4.89 & 2.41 & 3.90 & 8.30 & 7.87 & 9.23 & 9.33 & 9.58 & 0.94 & 1.27 & 1.79 \\
\hline $\mathrm{Fe}_{2} \mathrm{O}_{3}$ & 1.75 & 0.84 & 1.36 & 2.00 & 1.60 & 3.37 & 3.71 & $4 \cdot 36$ & 0.43 & 0.53 & 0.61 \\
\hline $\mathrm{MgO}$ & 12.52 & 7.63 & 11.87 & 7.35 & 1.25 & 2.82 & 3.56 & 3.09 & 15.59 & 13.54 & 11.50 \\
\hline $\mathrm{CaO}$ & 10.69 & 15.66 & 9.69 & 5.55 & 5.05 & 7.68 & 7.23 & 6.74 & 11.52 & 15.28 & 16.95 \\
\hline $\mathrm{Na}_{2} \mathrm{O}$ & 7.37 & 10.51 & 10.37 & 10.76 & 5.33 & 6.65 & 6.63 & 7.60 & 14.27 & 7.43 & 5.63 \\
\hline $\mathrm{K}_{2} \mathrm{O}$ & 1.07 & 0.85 & 1.16 & 2.28 & 2.91 & 2.24 & 2.15 & 2.24 & 0.43 & 0.61 & 0.69 \\
\hline $\mathrm{TiO}_{2}$ & 0.22 & 0.12 & 0.17 & 0.29 & 0.22 & 0.40 & 0.42 & 0.45 & 0.05 & 0.07 & 0.09 \\
\hline $\mathrm{P}_{2} \mathrm{O}_{5}$ & 0.08 & 0.03 & 0.04 & 0.05 & 0.05 & 0.07 & 0.08 & 0.09 & 0.03 & 0.03 & 0.03 \\
\hline MnO & 0.04 & 0.02 & 0.04 & 0.04 & 0.04 & 0.06 & 0.06 & 0.06 & 0.01 & 0.01 & 0.01 \\
\hline $\mathrm{Cr}_{2} \mathrm{O}_{3}$ & 0.026 & 0.022 & 0.024 & 0.052 & 0.032 & 0.030 & 0.031 & 0.033 & 0.006 & 0.006 & 0.012 \\
\hline LOI & 24.30 & 27.00 & 21.80 & 14.40 & 1.40 & 16.70 & 18.10 & 4.10 & 27.10 & 27.70 & 25.80 \\
\hline Sum & 87.03 & 77.16 & 80.08 & 99.69 & 99.68 & 99.54 & 99.32 & 84.66 & 74.91 & 72.81 & 72.21 \\
\hline TOT/C & 3.15 & 1.79 & 2.74 & 1.29 & 1.01 & 2.03 & 1.98 & 1.72 & 4.38 & 3.47 & 2.89 \\
\hline TOT/S & 4.41 & 11.52 & 6.65 & 4.04 & 0.12 & 0.23 & 0.17 & 0.18 & 4.53 & 7.55 & 8.51 \\
\hline Sc & 4 & 2 & 3 & 5 & 4 & 9 & 10 & 10 & 1 & 1 & 2 \\
\hline$B a$ & 259 & 114 & 184 & 371 & 537 & 377 & 342 & 326 & 56 & 66 & 69 \\
\hline Co & 8 & 5 & 7 & 12 & 6 & 13 & 14 & 16 & 2 & 2 & 3 \\
\hline Cs & 5 & 2 & 4 & 4 & 5 & 10 & 11 & 11 & 2 & 3 & 2 \\
\hline$G a$ & 5 & 3 & 4 & 7 & 6 & 9 & 9 & 10 & 1 & 2 & 2 \\
\hline$H f$ & 2 & 1 & 1 & 2 & 3 & 3 & 2 & 3 & $o$ & 1 & 1 \\
\hline$N b$ & 4 & 2 & 4 & 4 & 4 & 7 & 8 & 9 & 1 & 1 & 2 \\
\hline$R b$ & 34 & 20 & 34 & 60 & 92 & 89 & 89 & 92 & 11 & 15 & 17 \\
\hline Sr & 2242 & 1957 & 1646 & 406 & 327 & 410 & 362 & 265 & 4339 & 2244 & 1014 \\
\hline Th & 3 & 2 & 4 & 4 & 5 & 7 & 8 & 9 & 1 & 1 & 1 \\
\hline u & 4 & 2 & 3 & 3 & 1 & 2 & 2 & 2 & 4 & 3 & 3 \\
\hline$v$ & 56 & 32 & 40 & 42 & 21 & 60 & 63 & 88 & 18 & 17 & 19 \\
\hline $\mathrm{Zr}$ & 55 & 30 & 38 & 65 & 99 & 91 & 88 & 113 & 12 & 17 & 28 \\
\hline Mo & 10 & 7 & 5 & 12 & 1 & 1 & 1 & 1 & 40 & 8 & 8 \\
\hline $\mathrm{Cu}$ & 8 & 6 & 9 & 10 & 5 & 19 & 19 & 20 & 3 & 4 & 4 \\
\hline$P b$ & 4 & 2 & 4 & 4 & 5 & 12 & 45 & 50 & 4 & 2 & 3 \\
\hline$Z n$ & 1199 & 839 & 1103 & 386 & 1110 & 2109 & 3643 & 645 & 541 & 1186 & 724 \\
\hline $\mathrm{Ni}$ & 58 & 29 & 42 & 62 & 25 & 92 & 93 & 102 & 11 & 16 & 19 \\
\hline As & 39 & 13 & 11 & 20 & 17 & 15 & 25 & 38 & 22 & 15 & 15 \\
\hline$Y$ & 7 & 4 & 6 & 10 & 9 & 14 & 14 & 15 & 2 & 2 & 3 \\
\hline$L a$ & 10.20 & 5.70 & 9.80 & 11.40 & 12.10 & 16.90 & 17.70 & 18.10 & 2.60 & 2.90 & 4.40 \\
\hline $\mathrm{Ce}$ & 19.10 & 10.70 & 17.20 & 20.80 & 22.70 & 33.60 & 34.30 & 35.20 & 4.80 & 6.00 & 8.80 \\
\hline $\operatorname{Pr}$ & 2.09 & 1.16 & 1.87 & 2.39 & 2.53 & 3.65 & 3.76 & 3.91 & 0.48 & 0.61 & 0.98 \\
\hline$N d$ & 7.80 & 4.70 & 7.80 & 8.60 & 8.90 & 14.50 & 15.30 & 14.00 & 1.60 & 2.40 & 4.00 \\
\hline$S m$ & 1.41 & 0.76 & 1.17 & 1.66 & 1.70 & 2.61 & 2.69 & 2.82 & 0.27 & 0.41 & 0.68 \\
\hline$E u$ & 0.38 & 0.21 & 0.31 & 0.50 & 0.45 & 0.63 & 0.65 & 0.70 & 0.07 & 0.11 & 0.16 \\
\hline$G d$ & 1.23 & 0.63 & 1.10 & 1.65 & 1.46 & 2.41 & 2.52 & 2.52 & 0.26 & 0.43 & 0.58 \\
\hline$T b$ & 0.20 & 0.12 & 0.18 & 0.27 & 0.24 & 0.40 & 0.43 & 0.44 & 0.04 & 0.07 & 0.08 \\
\hline Dy & 1.19 & 0.72 & 0.89 & 1.45 & 1.34 & 2.32 & 2.38 & 2.44 & 0.29 & 0.39 & 0.56 \\
\hline Ho & 0.22 & 0.14 & 0.19 & 0.33 & 0.31 & 0.46 & 0.49 & 0.54 & 0.05 & 0.08 & 0.09 \\
\hline Er & 0.65 & 0.33 & 0.54 & 0.92 & 0.87 & 1.39 & 1.42 & 1.55 & 0.15 & 0.22 & 0.26 \\
\hline$T m$ & 0.10 & 0.07 & 0.08 & 0.15 & 0.15 & 0.23 & 0.23 & 0.23 & 0.02 & 0.04 & 0.04 \\
\hline$Y b$ & 0.65 & 0.41 & 0.56 & 0.89 & 0.93 & 1.27 & 1.42 & 1.53 & 0.16 & 0.21 & 0.28 \\
\hline Lu & 0.09 & 0.06 & 0.09 & 0.14 & 0.14 & 0.21 & 0.22 & 0.25 & 0.02 & 0.03 & 0.04 \\
\hline$\sum R E E$ & $45 \cdot 31$ & 25.71 & 41.78 & 51.15 & 53.82 & 80.58 & 83.51 & 84.23 & 10.81 & 13.90 & 20.95 \\
\hline$\Sigma L R E E / \Sigma H R E E$ & 9.38 & 9.28 & 10.42 & 7.73 & 8.81 & 8.20 & 8.10 & 7.79 & 9.85 & 8.38 & 9.77 \\
\hline$(L a / Y b)_{c n}$ & 10.86 & 9.63 & 12.12 & 8.87 & 9.01 & 9.21 & 8.63 & 8.19 & 11.25 & 9.56 & 10.88 \\
\hline$\left(\mathrm{Ce} / \mathrm{C} e^{*}\right)_{c n}$ & 0.99 & 1.00 & 0.96 & 0.96 & 0.98 & 1.03 & 1.01 & 1.00 & 1.03 & 1.08 & 1.02 \\
\hline$\left(E u / E u^{*}\right)_{c n}$ & 0.88 & 0.92 & 0.83 & 0.92 & 0.87 & 0.76 & 0.76 & 0.80 & 0.80 & 0.80 & 0.77 \\
\hline
\end{tabular}


Table 1b. Major (\%) and trace element (ppm) concentrations (continued). (-: below detection limits, nv: no value)

\begin{tabular}{|c|c|c|c|c|c|c|c|c|c|c|c|}
\hline & $C_{4}$ & $D_{1}$ & $D_{2}$ & $D_{3}$ & $E_{1}$ & $E_{2}$ & $E_{3}$ & $E_{4}$ & $E_{5}$ & Average & PAAS \\
\hline $\mathrm{SiO}_{2}$ & 5.86 & 20.87 & 46.55 & 43.03 & 9.56 & 13.37 & 11.62 & 3.14 & 4.59 & 25.08 & 62.80 \\
\hline $\mathrm{Al}_{2} \mathrm{O}_{3}$ & 1.32 & 4.02 & 8.88 & 8.65 & 2.39 & 3.22 & 2.63 & 0.61 & 1.08 & 4.62 & 18.90 \\
\hline $\mathrm{Fe}_{2} \mathrm{O}_{3}$ & 0.67 & 1.70 & 2.81 & 2.96 & 1.12 & 1.44 & 1.25 & 0.26 & 0.61 & 1.67 & 7.23 \\
\hline $\mathrm{MgO}$ & 9.19 & 6.13 & 3.72 & 4.38 & 5.73 & 9.30 & 15.42 & 11.26 & 10.26 & 8.31 & 2.20 \\
\hline $\mathrm{CaO}$ & 12.17 & 14.70 & 12.73 & 11.66 & 8.81 & 17.07 & 2.81 & 12.72 & 13.08 & 10.89 & 1.30 \\
\hline $\mathrm{Na}_{2} \mathrm{O}$ & 6.64 & 12.04 & 5.62 & 6.39 & 25.68 & 5.29 & 21.52 & 7.21 & 5.10 & 9.40 & 1.20 \\
\hline $\mathrm{K}_{2} \mathrm{O}$ & 10.36 & 1.00 & 1.91 & 2.06 & 0.64 & 0.78 & 0.82 & 10.02 & 10.64 & 2.74 & 3.70 \\
\hline $\mathrm{TiO}_{2}$ & 0.07 & 0.25 & 0.41 & 0.45 & 0.13 & 0.20 & 0.15 & 0.03 & 0.06 & 0.21 & 1.00 \\
\hline $\mathrm{P}_{2} \mathrm{O}_{5}$ & 0.02 & 0.04 & 0.08 & 0.08 & 0.01 & 0.04 & 0.03 & 0.04 & 0.02 & 0.05 & 0.16 \\
\hline $\mathrm{MnO}$ & - & 0.04 & 0.06 & 0.07 & 0.02 & 0.02 & 0.02 & - & - & 0.03 & 0.11 \\
\hline $\mathrm{Cr}_{2} \mathrm{O}_{3}$ & 0.006 & 0.097 & 0.103 & 0.084 & 0.012 & 0.024 & 0.016 & 0.002 & 0.004 & 0.03 & 0.02 \\
\hline LOI & 27.30 & 9.20 & 16.60 & 19.90 & 30.40 & 26.30 & 29.50 & 38.00 & 26.80 & 21.62 & $n v$ \\
\hline Sum & 73.59 & 70.06 & 99.51 & 99.73 & 84.50 & 77.01 & 85.74 & 83.32 & 72.27 & 84.64 & 104.59 \\
\hline TOT/C & 0.80 & 2.15 & 2.00 & 2.31 & 1.37 & 2.04 & 3.58 & 1.65 & 1.13 & 2.17 & $n v$ \\
\hline TOT/S & 12.47 & 4.52 & 1.42 & 0.64 & 2.67 & 8.58 & 0.65 & 12.10 & 13.10 & 5.20 & $n v$ \\
\hline Sc & 1 & 4 & 7 & 8 & 3 & 4 & 3 & - & 2 & 4 & 16 \\
\hline$B a$ & 64 & 211 & 414 & 363 & 102 & 179 & 95 & 54 & 58 & 212 & 650 \\
\hline Co & 2 & 15 & 15 & 14 & 4 & 6 & 4 & 1 & 2 & 8 & 23 \\
\hline$C_{s}$ & 3 & 3 & 4 & 5 & 5 & 7 & 5 & 2 & 3 & 5 & 15 \\
\hline$G a$ & 1 & 4 & 9 & 8 & 3 & 4 & 3 & 1 & 1 & 5 & 20 \\
\hline$H f$ & $o$ & 3 & 3 & 3 & 1 & 2 & 1 & o & $o$ & 2 & 5 \\
\hline$N b$ & 1 & 4 & 6 & 6 & 3 & 4 & 3 & 6 & 1 & 4 & 19 \\
\hline$R b$ & 19 & 31 & 60 & 65 & 23 & 27 & 24 & 12 & 20 & 42 & 160 \\
\hline Sr & 2427 & 2370 & 1921 & 445 & 2039 & 3737 & 882 & 4030 & 2640 & 1785 & 200 \\
\hline Th & 1 & 4 & 6 & 6 & 2 & 3 & 2 & 3 & 1 & 4 & 15 \\
\hline$u$ & 2 & 3 & 2 & 2 & 2 & 4 & 3 & 3 & 1 & 3 & 3 \\
\hline$v$ & 15 & 64 & 75 & 79 & 28 & 36 & 31 & 11 & 14 & 40 & 150 \\
\hline$Z r$ & 16 & 84 & 113 & 110 & 31 & 73 & 42 & 14 & 20 & 57 & 210 \\
\hline Mo & 7 & 7 & 3 & 1 & 7 & 19 & 20 & 15 & 5 & 9 & 1 \\
\hline $\mathrm{Cu}$ & 4 & 9 & 15 & 15 & 7 & 7 & 9 & 2 & 3 & 9 & 50 \\
\hline$P b$ & 2 & 7 & 3 & 15 & 7 & 19 & 20 & 2 & 3 & 11 & 20 \\
\hline$z n$ & 521 & 1346 & 664 & 317 & 541 & 801 & 2065 & 1941 & 640 & 1116 & 85 \\
\hline $\mathrm{Ni}$ & 17 & 65 & 89 & 99 & 27 & 30 & 31 & 8 & 14 & 47 & 55 \\
\hline As & 10 & 19 & 5 & 4 & 19 & 29 & 34 & 11 & 8 & 18 & $n v$ \\
\hline Y & 2 & 7 & 13 & 13 & 4 & 6 & 4 & 1 & 2 & 7 & 27 \\
\hline$\angle a$ & 2.90 & 9.70 & 16.30 & 16.00 & 5.60 & 9.50 & 7.10 & 1.90 & 2.80 & 9.18 & 38.00 \\
\hline $\mathrm{Ce}$ & 5.40 & 18.60 & 30.30 & 30.60 & 11.40 & 18.60 & 13.60 & 3.90 & 5.00 & 17.53 & 80.00 \\
\hline$P r$ & 0.60 & 2.14 & 3.37 & 3.36 & 1.22 & 2.02 & 1.43 & 0.40 & 0.53 & 1.93 & 8.83 \\
\hline$N d$ & 2.30 & 7.40 & 11.70 & 12.50 & 4.70 & 7.90 & 5.70 & 1.30 & 2.00 & 7.26 & 32.00 \\
\hline $\mathrm{Sm}$ & 0.44 & 1.51 & 2.47 & 2.47 & 0.86 & 1.23 & 0.98 & 0.26 & 0.37 & 1.34 & 5.60 \\
\hline$E u$ & 0.10 & 0.36 & 0.65 & 0.67 & 0.20 & 0.30 & 0.25 & 0.07 & 0.10 & 0.34 & 1.10 \\
\hline$G d$ & 0.39 & 1.42 & 2.25 & 2.10 & 0.78 & 1.16 & 0.85 & 0.29 & 0.36 & 1.22 & 4.70 \\
\hline$T b$ & 0.06 & 0.21 & 0.39 & 0.38 & 0.12 & 0.17 & 0.13 & 0.04 & 0.06 & 0.20 & 0.77 \\
\hline$D y$ & 0.42 & 1.17 & 2.10 & 2.07 & 0.63 & 0.98 & 0.71 & 0.19 & 0.31 & 1.13 & 4.40 \\
\hline Ho & 0.06 & 0.22 & 0.44 & 0.44 & 0.12 & 0.20 & 0.12 & 0.04 & 0.05 & 0.23 & 1.00 \\
\hline$E r$ & 0.22 & 0.76 & 1.33 & 1.27 & 0.32 & 0.59 & 0.41 & 0.09 & 0.16 & 0.67 & 2.90 \\
\hline$T m$ & 0.03 & 0.11 & 0.21 & 0.20 & 0.05 & 0.08 & 0.06 & 0.01 & 0.02 & 0.11 & 0.41 \\
\hline$Y b$ & 0.20 & 0.78 & 1.43 & 1.33 & 0.42 & 0.64 & 0.43 & 0.14 & 0.19 & 0.69 & 2.80 \\
\hline Lu & 0.03 & 0.12 & 0.20 & 0.20 & 0.06 & 0.08 & 0.06 & 0.01 & 0.02 & 0.10 & 0.40 \\
\hline$\sum R E E$ & 13.15 & 44.50 & 73.14 & 73.59 & 26.48 & 43.45 & 31.83 & 8.64 & 11.97 & 41.93 & 182.91 \\
\hline$\Sigma L R E E / \Sigma H R E E$ & 8.26 & 8.22 & 7.68 & 8.13 & 9.51 & 10.06 & 10.40 & 9.58 & 9.15 & 8.55 & 9.46 \\
\hline$(L a / Y b)_{c n}$ & 10.04 & 8.61 & 7.89 & 8.33 & 9.23 & 10.28 & 11.43 & 9.40 & 10.20 & 9.17 & 9.40 \\
\hline$\left(\mathrm{Ce} / \mathrm{C} e^{*}\right)_{c n}$ & 0.98 & 0.98 & 0.98 & 1.00 & 1.05 & 1.02 & 1.02 & 1.07 & 0.98 & 1.00 & 1.05 \\
\hline$\left(E u / E u^{*}\right)_{c n}$ & 0.73 & 0.75 & 0.84 & 0.89 & 0.74 & 0.76 & 0.83 & 0.77 & 0.83 & 0.82 & 0.65 \\
\hline
\end{tabular}


tic cluster in close similarity (Fig. 8) Since this situation directly controls the chemical concentrations of major oxides in the clastic phase, diagrams using major oxides for provenance determination becomes useless. Therefore, trace elements whose concentrations are associated with clastic cluster were used in this study (Fig.8).

Rare earth elements (REEs) exhibit coherent, insoluble and mostly immobile geochemical behaviours in their trivalent states [33, 37]. They are transported as suspension loads or by holding to fine-grained detritus during weathering, erosion, recycling and sedimentation [38]. REEs are quantitatively transferred to the clastic sedimentary records and is subsequently unaffected by secondary processes such as diagenesis and metamorphism. [39].

Basic rocks have lower Light REE ( $\left.\mathrm{LREE}_{\mathrm{La}-\mathrm{Sm}}\right)$ contents compared to Heavy REE ( $\mathrm{HREE}_{\mathrm{Gd}-\mathrm{Lu}}$ ) and do not contain Eu anomaly. However silicic rocks have higher LREE/HREE ratios and large negative Eu anomalies [40]. Due to their redox properties, $\mathrm{Eu}(+2 /+3)$ and $\mathrm{Ce}(+3 /+4)$ may behave differently from other trivalent REEs. The existence of the negative $\mathrm{Eu}$ anomaly is generally attributed to the retention of $\mathrm{Eu}$ by plagioclase, which is stable up to $40 \mathrm{~km}$ depth and under highly reducing ambient conditions. On the other hand, Ce tends to oxidize easily under surface conditions. Therefore, Ce anomaly occurs depending on whether the environment is oxidative or reductive [41].

REE concentrations of the samples are significantly lower than PAAS (Fig. 9). But the values of average LREE/ HREE, $(\mathrm{La} / \mathrm{Yb})_{\mathrm{cn}},(\mathrm{La} / \mathrm{Sm})_{\mathrm{cn}}$, and $(\mathrm{Gd} / \mathrm{Lu})_{\mathrm{cn}}$ ratios are getting closer to PAAS (Table 1). The Ce anomaly is not obvious. The effect of negative Eu anomaly is lower than that of PAAS. The specific Eu excess is probably due to plagioclase contribution from the source. The average REE pattern, which shows similarity to PAAS, except for the low negative Eu anomaly, suggests a cratonic provenance.

Elements potentially helpful for provenance identification are found in different concentrations in silicic and basic rocks. REEs, $\mathrm{Zr}, \mathrm{Ba}$ and Th concentrations are higher in silicic sources, while $\mathrm{Sc}, \mathrm{Ni}$ and $\mathrm{Co}$ concentrations are higher in basic sources [42]. These elements are also immobile and are not fractionated during sedimentary processes. Because of these features concentrations of these elements in the source rock is preserved in sediments [43].

Comparing the ratios of these preservative trace elements to each other with the average igneous rock compositions is useful to reveal the composition of the source [44]. The average values of $\mathrm{La} / \mathrm{Sc}, \mathrm{La} / \mathrm{Co}, \mathrm{Th} / \mathrm{Sc}, \mathrm{Th} / \mathrm{Co}, \mathrm{Zr} /$ $\mathrm{Sc}, \mathrm{Zr} / \mathrm{Co}, \mathrm{Ba} / \mathrm{Sc}$, and $\mathrm{Ba} / \mathrm{Co}$ ratios obtained were compared with the compositional variations (granite, felsic volcanic,

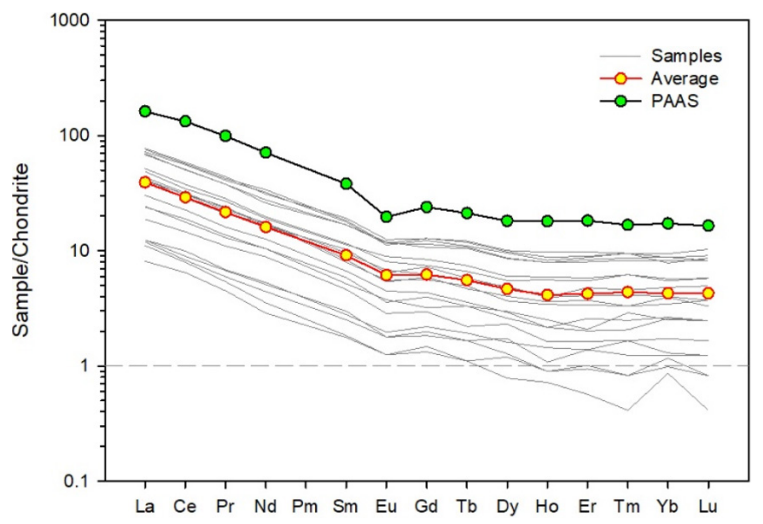

Figure 9. Comparison of REE with PAAS.

andesite and basalt) of Condie [45] (Table 2). This comparison suggests a provenance in "silicic-intermediate magmatic" composition for the lake sediments.

Considering the topographic elevation difference and the drainage network reaching the lake, the magmatic and metamorphic complex of the Kırşehir Massif in the eastnortheast of the lake is the most likely the source for the sediments [27, 46-50].

Table 2. Critical element ratios for provenance.

\begin{tabular}{cccccc}
\hline Rocks & *Granite & *Felsic Volcanic & *Andesite & *Basalt & Tuz Lake \\
\hline La/Sc & 8.00 & 2.15 & 1.11 & 0.33 & 2.36 \\
La/Co & 13.33 & 4.67 & 0.91 & 0.31 & 1.37 \\
Th/Sc & 3.60 & 0.78 & 0.22 & 0.07 & 0.83 \\
Th/Co & 6.00 & 1.70 & 0.18 & 0.07 & 0.59 \\
$\mathrm{Zr} / \mathrm{SC}$ & 50.00 & 16.54 & 8.89 & 3.97 & 14.25 \\
$\mathrm{Zr} / \mathrm{Co}$ & 83.33 & 35.83 & 7.27 & 3.74 & 8.45 \\
$\mathrm{Ba} / \mathrm{SC}$ & 160.00 & 65.38 & 36.11 & 12.42 & 53.55 \\
$\mathrm{Ba} / \mathrm{Co}$ & 266.67 & 141.67 & 29.55 & 11.71 & 31.50 \\
\hline \multicolumn{5}{r}{} \\
\hline
\end{tabular}

\section{Tectonic Setting}

Trace element diagrams of Bhatia and Crook [51] are frequently used to determine the tectonic setting of the source area. These diagrams were found reliable by LaMaskin et al. [52]. In this study, the La-Th-Sc diagram was used (Fig. 10). In the diagram, the tectonic settings are divided into four sections. These are A-Oceanic Island Arc, B-Continental Island Arc, C-Active continental margin, and D-Passive continental margin. In the diagram, the sample average falls on the "Continental Island Arc" region. This setting represents an arc on the continental margin along the subduction zone.

Görür et al. [18] suggested the existence of an Inner Taurus Ocean between the Menderes Taurus Block and the Kırșehir Block in the tectonic evolution model of the Tuzgölü Basin. According to this tectonic model, a continental 
arc developed on the Kirșehir Block by the subduction of the Inner Taurus Ocean. The "Continental Island Arc" tectonic setting of the diagram shows that the tectonic setting of the source region coincides with the tectonic setting of Görür et al. [18].

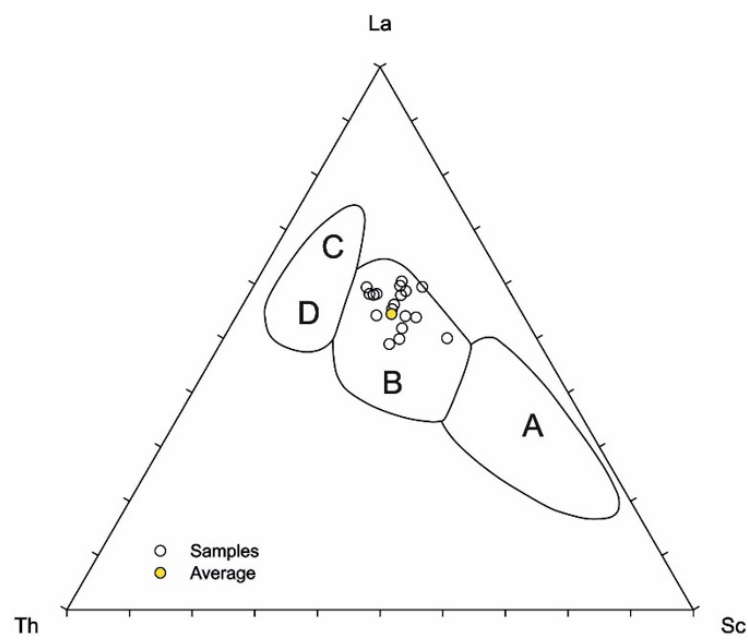

Figure 10. La-Th-Sc tectonic setting diagram [51]. A-Oceanic Island Arc, B-Continental Island Arc, C-Active continental margin, and D-Passive continental margin.

Furthermore, Yapıcı et al. [53], compared the Central Anatolian granitoids geochemically and stated that they were classified as well-developed calc-alkaline. These granitoids in the source area also support the tectonic setting model associated with the subduction.

\section{CONCLUSION}

Tuz Lake deposits sampled with cores with a depth not exceeding one meter, were determined to have halite, polyhalite, calcite, magnesite, dolomite, huntite, quartz, and albite minerals by the standard XRD analyses. In the clay fraction XRD analysis, montmorillonite and vermiculite minerals were detected. The geostatistical analyses show four groups namely Clastic, Hydrothermal, Evaporite-carbonate and Evaporite-sulfate. LREE enriched REE pattern suggests "cratonic" provenance except for the low negative $\mathrm{Eu}$ anomaly. The low $\mathrm{Eu}$ anomaly indicates that a plagioclase-rich source contributed to the sediments. Critical element ratios for provenance such as $\mathrm{La} / \mathrm{Sc}, \mathrm{La} /$ $\mathrm{Co}$, Th/Sc, Th/Co, Zr/Sc, Zr/Co, Ba/Sc, and Ba/Co suggest provenance in "acidic-intermediate magmatic" composition. The most likely candidate for provenance in this composition is the Kırşehir Massif, considering the topography and catchment area. In the La-Th-Sc diagram, the tectonic setting of the source region was found as the Continental Island Arc.

\section{ACKNOWLEDGEMENTS}

This study is derived from some part of Mehmet Yavuz HÜSEYINCA's Ph.D thesis, which was financially supported by Selçuk University Research Fund (09101002, BAP). The authors thank to anonymous reviewers for their constructive contributions to the study.

\section{CONFLICT OF INTEREST}

Authors approve that to the best of their knowledge, there is not any conflict of interest or common interest with an institution/organization or a person that may affect the review process of the paper.

\section{AUTHOR CONTRIBUTION}

First author: Conceptualization, methodology, software, investigation, writing-review and editing. Second author: Conceptualization, methodology, supervision, project administration.

\section{REFERENCES}

1. Çamur MZ, Mutlu H. Tuz Gölü'ndeki mineral çökeliminin termodinamik değerlendirilimi. Türkiye Jeoloji Bülteni. 38 2, (1995), 67-73.

2. Erol O. Tuz Gölü Havzasının jeoloji ve jeomorfolojisi (Genç tektonik hareketler, pluvial göl sekileri ve potas-tuz teşekkül şartları yönünden bir araştırma). TÜBİTAK, (26), 1969.

3. Ormeci C, Ekercin S. An assessment of water reserve changes in Salt Lake, Turkey, through multi-temporal Landsat imagery and real-time ground surveys. Hydrological Processes. 21, 11, (2007), 1424-1435.

4. Aydın F, Erlat E, Türkeş M. Impact of climate variability on the surface of Lake Tuz (Turkey), 1985-2016. Regional Environmental Change. 20, 2, (2020), 68.

5. Hüseyinca MY. Mineralogical and geochemical characteristics of the sediments in Lake Tuz and the close vicinity (in Turkish). Ph.D. Thesis, Selçuk University, Konya, 2015.

6. Kashima K. Environmental and climatic changes during the last 20,000 years at Lake Tuz, Central Turkey. Catena. 48, 1-2, (2002), 3-20.

7. Kılıç Ö, Kilıç AM. Recovery of salt co-products during the salt production from brine. Desalination. 186, 1, (2005), 11-19.

8. Irion G, Müller G. Huntite, dolomite, magnesite, and polyhalite, of recent age from Tuz Gölü, Turkey. Nature. 220, (1968), 1309-1310.

9. Uygun A, Şen E. Tuz Gölü Havzası ve doğal kaynakları I: Tuz Gölü suyunun jeokimyası. Bulletin of the Geological Society of Turkey. 21, (1978), 113-120.

10. Çamur MZ, Mutlu H. Major-ion geochemistry and mineralogy of the Salt Lake (Tuz Gölü) basin, Turkey. Chemical geology. 127, 4, (1996), 313-329.

11. Kılıç Ö, Kılıç AM. Salt crust mineralogy and geochemical evolution 
of the Salt Lake (Tuz Gölü), Turkey. Scientific Research and Essays 5, 11, (2010), 1317-1324.

12. Şenel M. Turkiye Jeoloji Haritasi/Geological Map of Turkey, scale 1:500,000, Maden Tetkik Arama Genel Müdürlüğü, Ankara, 2002.

13. Tekin E, Ayyildiz T, Gündoğan İ, Orti F. Modern halolites (halite oolites) in the Tuz Gölü, Turkey. Sedimentary Geology. 195, 3, (2007), 101-112.

14. Aydemir A, Ateş A. Structural interpretation of the Tuzgolu and Haymana Basins, Central Anatolia, Turkey, using seismic, gravity and aeromagnetic data. Earth Planets and Space. 58, 8, (2006), 951961.

15. Arıkan Y. Tuz Gölü havzasının jeolojisi ve petrol imkanları. M.T.A. Dergisi. 85, (1975), 17-38.

16. Aydemir A. Hydrocarbon potential of the Tuzgolu (Salt Lake) Basin, Central Anatolia, Turkey: A comparison of geophysical investigation results with the geochemical data. Journal of Petroleum Science and Engineering. 61, 1, (2008), 33-47.

17. Clark M, Robertson A. Uppermost Cretaceous-Lower Tertiary Ulukışla Basin, south-central Turkey: sedimentary evolution of part of a unified basin complex within an evolving Neotethyan suture zone. Sedimentary Geology. 173, 1, (2005), 15-51.

18. Görür N, Oktay FY, Seymen İ, Şengör AMC. Palaeotectonic evolution of the Tuzgölü basin complex, Central Turkey: sedimentary record of a Neo-Tethyan closure, In: J. E. Dixon A H. F. Robertson (Eds.), The geological evolution of the eastern mediterranean, Geological Society Special Publications, London, pp. 467-482, 1984.

19. Çemen I, Göncüoglu MC, Dirik K. Structural evolution of the Tuzgölü basin in Central Anatolia, Turkey. The Journal of geology. 107, 6, (1999), 693-706.

20. Yıldırım C. Relative tectonic activity assessment of the Tuz Gölü Fault Zone; Central Anatolia, Turkey. Tectonophysics. 630, (2014), 183-192.

21. Fernandez-Blanco D, Bertotti G, Çiner A. Cenozoic tectonics of the Tuz Gölü basin (central Anatolia plateau, Turkey). Turkish Journal of Earth Sciences. 22, 5, (2013), 715-738

22. Dirik K, Erol O. Tectonomorphologic evolution of Tuzgölü and surrounding area, central Anatolia-Turkey. Turkish Association of Petroleum Geologists Special Publication. 5, (2003), 27-46.

23. Seymen İ. Kaman dolayında Kırşehir Masifinin jeolojisi. Doçentlik Tezi, İ.T.Ü. Maden Fakültesi, İstanbul, 1982.

24. Göncüoğlu MC. Structural and stratigraphic framework of the central Anatolian Tertiary Basins. IGCP Project Early Paleogene Benthos Third Meeting, Ankara. 1992.

25. Koçak K, Zedef V, Kansun G. Magma mixing/mingling in the Eocene Horoz (Nigde) granitoids, Central southern Turkey: evidence from mafic microgranular enclaves. Mineralogy and Petrology. 103, 1-4, (2011), 149-167.

26. Okay AI, Tüysüz O. Tethyan sutures of northern Turkey. Geological Society, London, Special Publications. 156, 1, (1999), 475-515.

27. Kuşcu İ, Gençalioğlu Kuşcu G, Meinert LD, Floyd PA. Tectonic setting and petrogenesis of the Çelebi granitoid, (KırıkkaleTurkey) and comparison with world skarn granitoids. Journal of Geochemical Exploration. 76, 3, (2002), 175-194.

28. Göncüoğlu MC, Toprak V, Kuşcu İ, Erler A, Olgun E. Geology of the western part of the central Anatolian Massif, Part 1: Southern part. Turkish Petroleum Corporation (TPAO), 1991.

29. Kocak K, Leake BE. The petrology of the Ortakoy district and its ophiolite at the western edge of the Middle anatolian Massif, Turkey Journal of African Earth Sciences. 18, 2, (1994), 163-174.

30. Kocak K, Isık F, Arslan M, Zedef V. Petrological and source region characteristics of ophiolitic hornblende gabbros from the Aksaray and Kayseri regions, central Anatolian crystalline complex, Turkey. Journal of Asian Earth Sciences. 25, 6, (2005), 883-891.

31. Kashima K. The quantitative reconstruction of salinity changes using diatom assemblages in inland saline lakes in the central part of Turkey during the Late Quaternary. Quaternary International. 105, 1, (2003), 13-19.

32. Anders E, Grevesse N. Abundances of the elements: Meteoritic and solar. Geochimica et Cosmochimica Acta. 53, 1, (1989), 197-214.

33. Taylor SR, McLennan SM. The continental crust: Its composition and evolution, Blackwell Scientific Publications, Oxford, 1985.

34. Cullers RL. The geochemistry of shales, siltstones and sandstones of Pennsylvanian-Permian age, Colorado, USA: implications for provenance and metamorphic studies. Lithos. 51, 3, (2000), 181-203.

35. Hiscott RN. Ophiolitic source rocks for Taconic-age flysch: Traceelement evidence. Geological Society of America Bulletin. 95, 11, (1984), 1261-1267.

36. Hallberg RO. A Geochemical Method for Investigation of Paleoredox Conditions in Sediments. Ambio Special Report. 4, (1976), 139-147.

37. Cullers RL. The controls on the major- and trace-element evolution of shales, siltstones and sandstones of Ordovician to tertiary age in the Wet Mountains region, Colorado, U.S.A. Chemical geology. 123, 1-4, (1995), 107-131.

38. McLennan SM, Taylor SR. Sedimentary rocks and crustal evolution: Tectonic setting and secular trends. The Journal of geology. 99, 1, (1991), 1-21

39. Condie KC. Another look at rare earth elements in shales. Geochimica et Cosmochimica Acta. 55, 9, (1991), 2527-2531.

40. Cullers RL, Graf JL. Rare earth elements in igneous rocks of the continental crust: predominantly basic and ultrabasic rocks, In: Rare earth element geochemistry, Elsevier Amsterdam, pp. 237-274, 1984.

41. McLennan SM, Taylor SR. Geology, geochemistry and natural abundances of the Rare Earth Elements, In: D. A. Atwood R. A. Scott (Eds.), Encyclopedia of Inorganic and Bioinorganic Chemistry, John Wiley \& Sons, Ltd, pp. 19, 2012.

42. Cullers RL, Podkovyrov VN. The source and origin of terrigenous sedimentary rocks in the Mesoproterozoic Ui group, southeastern Russia. Precambrian Research. 117, 3-4, (2002), 157-183.

43. Armstrong-Altrin JS, Lee YI, Verma SP, Ramasamy S. Geochemistry of Sandstones from the Upper Miocene Kudankulam Formation, Southern India: Implications for Provenance, Weathering, and Tectonic Setting. Journal of Sedimentary Research. 74, 2, (2004), 285-297.

44. Cullers RL, Basu A, Suttner LJ. Geochemical signature of provenance in sand-size material in soils and stream sediments near the Tobacco Root batholith, Montana, U.S.A. Chemical geology. 70, 4, (1988), 335-348.

45. Condie KC. Chemical composition and evolution of the upper continental crust : Contrasting results from surface samples and shales. Chemical geology. 104, (1993), 1-37.

46. Boztuğ D, Harlavan Y. K-Ar ages of granitoids unravel the stages of Neo-Tethyan convergence in the eastern Pontides and central Anatolia, Turkey. International Journal of Earth Sciences. 97, 3, (2008), 585-599.

47. Boztuğ D, Jonckheere RC, Heizler M, Ratschbacher L, Harlavan Y, Tichomirova M. Timing of post-obduction granitoids from intrusion through cooling to exhumation in central Anatolia, Turkey. Tectonophysics. 473, 1, (2009), 223-233.

48. Köksal S, Romer RL, Göncüoglu MC, Toksoy-Köksal F. Timing of post-collisional $\mathrm{H}$-type to A-type granitic magmatism: $\mathrm{U}-\mathrm{Pb}$ titanite ages from the Alpine central Anatolian granitoids (Turkey). 
International Journal of Earth Sciences. 93, 6, (2004), 974-989.

49. Koçak K, Zedef V. Interaction of the lithospheric mantle and crustal melts for the generation of the Horoz pluton (Niğde, Turkey) whole-rock geochemical and $\mathrm{Sr}-\mathrm{Nd}-\mathrm{Pb}$ isotopic evidence. Estonian Journal of Earth Sciences. 65, 3, (2016), 138-160.

50. Nurlu N, Yapıcı N. Ortaköy Granitoyidi'nin petrografik ve jeokimyasal özellikleri (Yaylak/Aksaray). Çukurova Üniversitesi Mühendislik Mimarlık Fakültesi Dergisi. 29, 2, (2014), 69-78.

51. Bhatia MR, Crook KAW. Trace element characteristics of graywackes and tectonic setting discrimination of sedimentary basins. Contributions to Mineralogy and Petrology. 92, 2, (1986), 181-193.

52. LaMaskin TA, Dorsey RJ, Vervoort JD. Tectonic controls on mudrock geochemisry, Mesozoic rocks of eastern Oregon and western Idaho, USA: Implications for cordilleran tectonics. Journal of Sedimentary Research. 78, 12, (2008), 765-783.

53. Yapıcı N, Nurlu N, Güneyli H. Comparison of Ortaköy/Yaylak granitoid (Aksaray) with the other intrusions. Paper presented at the 2. international Turkish world engineering and science congress, Antalya. 7-10 November, pp. 252-260, 2019. 